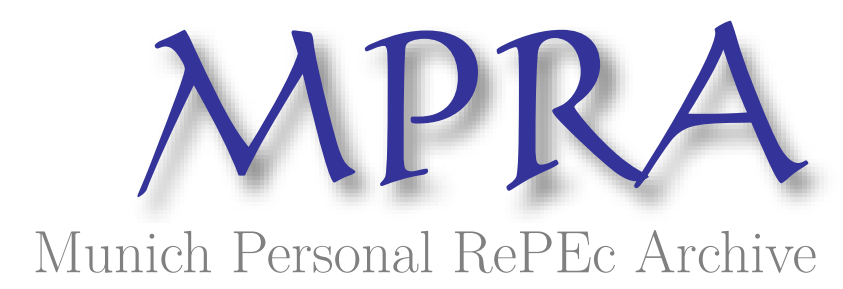

\title{
Information money fields of cyclic oscillations in nonlinear dynamic economic system
}

Ledenyov, Dimitri O. and Ledenyov, Viktor O.

James Cook University, Townsville, Australia

10 April 2015

Online at https://mpra.ub.uni-muenchen.de/63564/

MPRA Paper No. 63564, posted 11 Apr 2015 10:21 UTC 


\title{
Information money fields of cyclic oscillations in nonlinear dynamic economic system
}

\author{
Dimitri O. Ledenyov and Viktor O. Ledenyov
}

Abstract - Article introduces the notion of information money fields of the cyclic oscillations of the economic variables in the nonlinear dynamic economic system for the first time, and presents an original research on the Ledenyov theory on the information money fields of the cyclic oscillations of the economic variables in the nonlinear dynamic economic system. The Ledenyov theory on the information money fields of the cyclic oscillations of economic variables in the nonlinear dynamic economic system postulates that the economic continuous waves (the cyclic oscillations) have the information money fields in the nonlinear dynamic economic system, transmitting the economic/financial information in the nonlinear dynamic economic system. It is shown that the information money fields may interact with other cyclic oscillations and/or with the nonlinear dynamic economic system by means of the weak and strong interactions between the information money fields. We developed the MicroIMF software program to make the computer modeling of 1) the interactions between the information money fields of one cyclic oscillation and the information money fields of other cyclic oscillation(s) in the nonlinear dynamic economic system, 2) the interactions between the information money fields of cyclic oscillation and the nonlinear dynamic economic system itself, and 3) the density distributions of the information money fields by different cyclic oscillations (the economic continuous waves) in the nonlinear dynamic economic system. The MicroIMF software program can be used in the process of business cycles forecasting by the central banks with the purpose to make the strategic decisions on the monetary policies, financial stability policies, and by other financial institutions with the aim to perform the financial operations on the minimum capital allocation, countercyclical capital buffer creation, and capital investments.

JEL: E32, E43, E44, E53, E58, E61, G18, G21, G28

PACS numbers: 89.65.Gh, 89.65.-s, 89.75. Fb

Keywords: information money field of cyclic oscillation, generation of cyclic oscillations, amplitude of cyclic oscillation, frequency of cyclic oscillation, wavelength of cyclic oscillation, period of cyclic oscillation, phase of cyclic oscillation, mixing of cyclic oscillations, harmonics of cyclic oscillation, nonlinearities of cyclic oscillation, Juglar fixed investment cycle, Kitchin inventory cycle, Kondratieff long wave cycle, Kuznets infrastructural investment cycle, econophysics, econometrics, nonlinear dynamic economic system, macroeconomics. 


\section{Introduction}

The evolutionary progress in the economic science in view of the disruptive innovation influence results in the creation of the empirical theories, models, and schemes in the economics, aiming both:

1) to understand the nature of economic processes, and

2) to characterize the fundamental/applied properties of the economic processes, as discussed in the academic literature in Joseph Penso de la Vega (1668, 1996), Mortimer (1765), Bagehot (1873, 1897), von Böhm-Bawerk (1884, 1889, 1921), Hirsch (1896), Bachelier (1900), Schumpeter (1906, 1911, 1933, 1939, 1961, 1939, 1947), Slutsky (1910, 1915 1923), von Mises (1912), Hayek (1945), Ellis, Metzler (1949), Friedman (1953), Baumol (1957), Debreu (1959), Dodd (2014).

The modern economics science is presently divided on the three main subjects, which are intensively researched:

1) Macroeconomics, which considers the macro-processes in the economics;

2) Microeconomics, which deals with the micro-processes in the economics;

3) Nanoeconomics, which is focused on the nano-processes in the economics.

In the macroeconomics, the cyclic oscillations of economic variables with the different amplitudes, frequencies and phases have been discovered as explained in Ledenyov $D O$, Ledenyov VO (2013c):

"Juglar (1862) discovered the 7-11 years Juglar fixed investment cycle, which is still in the scope of research interest by many scientists in Schumpeter (1939), Grinin, Korotayev, Malkov (2010), Korotayev, Tsirel (2010), Ledenyov V O, Ledenyov D O (2012), Ledenyov D O, Ledenyov V O (2013). It makes sense to explain that Schumpeter (1939) showed that there are the four stages in the Juglar cycle: 1) expansion; 2) crisis; 3) recession; 4) recovery.

Kitchin (1923) proposed that there is the 3 - 7 years Kitchin inventory cycle. This proposition was investigated in Schumpeter (1939), Korotayev, Tsirel (2010), Ledenyov V O, Ledenyov D O (2012), Ledenyov D O, Ledenyov V O (2013).

Kondratieff (1922, 1925, 1926, 1928, 1935, 1984, 2002) made a significant contribution to the science of economics. The Kondratieff's early research was focused on the big cycles of conjuncture in the World economy in Kondratieff $(1922,1925,1926,1928)$. The discovery of the 45 - 60 years Kondratieff long wave cycle in Kondratieff, Stolper (1935) had a considerable impact on the science of economics. The Kondratieff's research achievements are comprehensively analyzed in Kondratieff $(1984,2002)$. Since that time, the Kondratieff long 
wave cycle has been a subject of intensive research by many scientists in Schumpeter (1939), Garvy (1943), Silberling (1943), Rostow (1975), Kuczynski (1978, 1982), Forrester (1978, 1981, 1985), Barr (1979), Van Duijn (1979, 1981, 1983), Eklund (1980), Mandel (1980), Van der Zwan (1980), Tinbergen (1981), Van Ewijk (1982), Cleary, Hobbs (1983), Glismann, Rodemer, Wolter (1983), Wallerstein (1984), Bieshaar, Kleinknecht (1984), Zarnowitz (1985), Summers (1986), Freeman (1987), Goldstein (1988), Solomou (1989), Berry (1991), Tylecote (1992), Metz (1992, 1998, 2006), Cooley (1995), Freeman, Louçã (2001), Modelski (2001, 2006), Perez (2002), Rennstich (2002), Rumyantseva (2003), Diebolt, Doliger (2006), Linstone (2006), Thompson (2007), Papenhausen (2008), Taniguchi, Bando, Nakayama (2008), Korotayev, Tsirel (2010), Ikeda, Aoyama, Fujiwara, Iyetomi, Ogimoto, Souma, Yoshikawa (2012), Ledenyov V O, Ledenyov D O (2012), Ledenyov D O, Ledenyov V O (2013).

Kuznets (1973) introduced the 15 - 25 years Kuznets infrastructural investment cycle in Kuznets (1973), based on his research on the cyclical fluctuations of the production and prices in Kuznets (1930). The researches on the nature of the Kuznets cycles were conducted by Abramovitz (1961), Rostow (1975), Solomou (1989); Diebolt, Doliger (2006, 2008), Korotayev, Tsirel (2010), Ledenyov V O, Ledenyov D O (2012), Ledenyov D O, Ledenyov V O (2013). Most recently, Korotayev, Tsirel (2010) conducted the spectral analysis and proposed that there is a tight connection between the Kondratieff long wave cycle and the Kuznets infrastructural investment cycle, suggesting that the Kuznets swings represent a third frequency harmonic of the main frequency oscillation, which is generated by the Kondratieff long wave cycle, hence the Kuznets cycle is not an independent oscillation in Korotayev, Tsirel (2010)."

The multiple origins of business cycles (cyclic oscillations) have been found as listed in Ledenyov D O, Ledenyov V O (2013c):

1) fluctuations in the aggregate demand in agreement with the Keynes theory;

2) fluctuations in the credit in accordance with the Minsky theory;

3) fluctuations in the technological innovations as explained in the real business cycle theory;

4) fluctuations in the land price in agreement with the George theory in George (1881, 2009);

5) fluctuations in the politics.

The different sophisticated scientific techniques to make:

1) detection,

2) filtering, and

3) measurements 
of cyclic oscillations in the macroeconomics, have been proposed by the scientists, resulting in a discovery of the following cyclic oscillations as noted in Ledenyov D O, Ledenyov V O (2013c):

1) 3 - 7 years Kitchin inventory cycle in Kitchin (1923);

2) 7-11 years Juglar fixed investment cycle in Juglar (1862);

3) 15 - 25 years Kuznets infrastructural investment cycle in Kuznets (1973);

4) 45 - 60 years Kondratieff long wave cycle in Kondratieff, Stolper (1935); and

5) 70+ Grand super-cycle.

Ledenyov D O, Ledenyov $V O(2013 c)$ made an interesting theoretical proposition that an interaction between the business cycles with the corresponding amplitude, frequency and phase and the nonlinear dynamic financial and economic systems can be classified into the two possible types of interactions:

1) Linear interaction,

2) Non-linear interaction,

Ledenyov D O, Ledenyov V O (2013c) made an additional crucial theoretical proposition that the following four nonlinear effects may originate as a result of the nonlinear interaction between the business cycles and the nonlinear dynamic financial and economic system:

1) Four Waves Mixing (FWM) effect,

2) Stimulated Brillouin Scattering (SBS) effect,

3) Stimulated Raman Scattering (SRS) effect,

4) Carrier-Induced Phase Modulation effect.

The scientific problem on the precise characterization of cyclic oscillations in the macroeconomics has been further researched and comprehensively discussed (in a chronological order) in George (1881, 2009), Schumpeter (1939), Burns, Mitchell (1946), Dupriez (1947), Samuelson (1947), Hicks (1950), Inada, Uzawa (1972), Bernanke (1979), Marchetti (1980), Kleinknecht (1981), Dickson (1983), Hodrick, Prescott (1997), Baxter, King (1999), Kim, Nelson (1999), McConnell, Pérez-Quirós (2000), Devezas, Corredine (2001, 2002), Devezas (editor) (2006), Arnord (2002), Stock, Watson (2002), Helfat, Peteraf (2003), Sussmuth (2003), Hirooka (2006), Kleinknecht, Van der Panne (2006), Jourdon (2008), Taniguchi, Bando, Nakayama (2008), Drehmann, Borio, Tsatsaronis (2011), Iyetomi, Nakayama, Yoshikawa, Aoyama, Fujiwara, Ikeda, Souma (2011), Ikeda, Aoyama, Fujiwara, Iyetomi, Ogimoto, Souma, Yoshikawa (2012), Swiss National Bank (2012, 2013), Uechi, Akutsu (2012), Central Banking Newsdesk (2013), Ledenyov D O, Ledenyov V O (2013c), Union Bank of Switzerland (2013), Wikipedia (2015). 


\section{Generation of information money fields by cyclic oscillations in nonlinear dynamic economic system}

Let us express our opinion that, in the academic literature, the considerable attention is paid to the cyclic oscillations of economic variables, which are normally characterized by the different amplitudes, frequencies and phases, for example: Juglar periodic oscillation in Juglar (1862), Kitchin periodic oscillation in Kitchin (1923), Kondratieff periodic oscillation in Kondratieff (1922, 1925, 1926, 1928, 1935, 1984, 2002), Kuznets periodic oscillation in Kuznets (1973). The ideas on the possible characterization of the cyclic oscillations of economic variables have been explored and summarized in Schumpeter (1939), Burns, Mitchell (1946), Hicks (1950), Bernanke (1979), Sussmuth (2003), Devezas (editor) (2006).

Let us note that there are the two possible scientific approaches in the commonly accepted research considerations on the cyclic oscillations of economic variables in the academic literature:

1) in terms of the frequency of the cyclic oscillations of economic variables, hence this terminology is close to the microwave engineering and microwave physics;

2 ) in terms of the wavelength of the cyclic oscillations of economic variables, hence this terminology is close to the optical engineering and optical physics.

The amplitude, frequency and phase parameters are normally used to characterize the cyclic oscillations of economic variables in the space-time domain in agreement with the theoretical representations in the physics.

The authors would like to highlight an interesting observation that the notion of the field is not used in application to the cyclic oscillations of economic variables in the time-space domains in the economics. It is necessary to explain that the notion of the abstract mathematical field has been introduced by the Euclid in the mathematics for the first time in Ledenyov $D O$, Ledenyov $V O$ (2015a). For example, in the mathematics, it is a well known fact that we can scientifically treat the field as the geometrical characteristics of the abstract mathematical space-time domains in Ledenyov D O, Ledenyov V O (2015a). Using the knowledge base on the nature and physical properties of the electromagnetic field, gravitation field, calibrating field, information field in the physics, we would like to assume that the cyclic oscillations in the nonlinear dynamic economic system, including the Juglar fixed investment cycle, Kitchin inventory cycle, Kondratieff long wave cycle, Kuznets infrastructural investment cycle, may have the information money fields in an analogy with the electromagnetic periodic oscillations, which can be characterized by the electric and magnetic fields in the theory of electrodynamics 
in the physics in Ledenyov $D O$, Ledenyov $V O$ (2015a). In our opinion, the information money fields of the cyclic oscillations of economic variables in the nonlinear dynamic economic system play an important role of the information transmission about the state of the source of the information money field in the nonlinear dynamic economic system.

The Ledenyov theory on the information money fields of the cyclic oscillations of economic variables in the nonlinear dynamic economic system postulates that the economic continuous waves (the cyclic oscillations) have the information money fields in the nonlinear dynamic economic system, which transmit the economic/financial information in the nonlinear dynamic economic system.

The authors think that the mathematical description of the structure of the information money fields can be done in parallel with the Maxwell electromagnetism theory and with the application of the Maxwell equations in the electrodynamics in the physics in Maxwell (1890), Ledenyov D O, Ledenyov VO (2015a), and as it is practically realized in the MicroIMF software program.

It follows from the Ledenyov theory on the information money fields of the cyclic oscillations of economic variables in the nonlinear dynamic economic system that:

1) the information money fields of one cyclic oscillation can interact with other information money fields of other cyclic oscillations, and/or

2) the information money fields of one cyclic oscillation can interact with the nonlinear dynamic economic system by means of the weak and strong interactions in the information money fields.

Therefore, in our opinion, the information money fields, which are associated with the Juglar fixed investment cycle, Kitchin inventory cycle, Kondratieff long wave cycle, Kuznets infrastructural investment cycle can interact with each other and with the medium such as the nonlinear dynamic economic system.

\section{MicroIMF software program to accurate characterize business cycles and create central bank strategy with optimal monetary and financial policies}

The authors believe that the Ledenyov theory on the information money fields of the cyclic oscillations in the nonlinear dynamic economic system can be used in the process of business cycles forecasting with the application of the complex algorithms and the parallel computing techniques at the supercomputers by: 
1) the central banks with the purpose to make the decisions on the monetary policies, financial stability policies, and

2) the commercial banks or financial institutions with the aim to perform the financial operations towards the minimum capital allocation, countercyclical capital buffer creation, and capital investments transactions.

We developed the MicroIMF software program to make the computer modeling of:

1) the interactions between the information money fields of one cyclic oscillation and the information money fields of other cyclic oscillation(s) in the nonlinear dynamic economic system,

2) the interactions between the information money fields of cyclic oscillation and the nonlinear dynamic economic system itself, and

3) the density distributions of the information money fields by different cyclic oscillations (the economic continuous waves) in the nonlinear dynamic economic system.

Let us note that the changes in the business cycle characteristics, caused by the nonlinear interaction between the business cycle and the nonlinear dynamic financial and economic systems, have to be taken to the consideration during the process of accurate characterization of the business cycle by the central banks.

Going from the econophysical analysis of the nonlinear dynamical financial and economic systems, we propose that the central bank must create the strategy towards the monetary policy and financial policies using the modeling data on the information money fields of the cyclic oscillations in the nonlinear dynamic economic system.

Presently, the MicroIMF software program has been developed with the application of object oriented programming languages and scrupulously tested by the authors.

\section{Conclusion}

The scientific article presents the Ledenyov theory on the information money fields of the cyclic oscillations of economic variables in the nonlinear dynamic economic system.

The Ledenyov theory on the information money fields of the cyclic oscillations of economic variables in the nonlinear dynamic economic system postulates that the economic continuous waves (the cyclic oscillations) have the information money fields in the nonlinear dynamic economic system, which transmit the economic/financial information in the nonlinear dynamic economic system.

In the research article, it is shown that: 
1) the information money fields of one cyclic oscillation can interact with other information money fields of other cyclic oscillations, and/or

2) the information money fields of one cyclic oscillation can interact with the nonlinear dynamic economic system by means of the weak and strong interactions in the information money fields.

We developed the MicroIMF software program to make the computer modeling of:

1) the interactions between the information money fields of one cyclic oscillation and the information money fields of other cyclic oscillation(s) in the nonlinear dynamic economic system,

2) the interactions between the information money fields of cyclic oscillation and the nonlinear dynamic economic system itself, and

3 ) the density distributions of the information money fields by different cyclic oscillations (the economic continuous waves) in the nonlinear dynamic economic system.

We think that the Ledenyov theory on the information money fields of cyclic oscillations in the nonlinear dynamic economic system and the MicroIMF software program can be used in the process of business cycles forecasting with the application of the complex algorithms and parallel computing techniques at the supercomputers by the central banks with the purpose to make the decisions on the monetary policies, financial stability policies and by other financial institutions with the aim to perform the financial operations on the minimum capital allocation, countercyclical capital buffer creation, and capital investments.

\section{Acknowledgement}

Prof. Joseph Alois Schumpeter started to think on the business cycles and economic development in the economics science at University of Czernowitz in the City of Czernowitz in the State of Ukraine in 1909 - 1911, completing the writing of his well known book on the business cycles in Schumpeter (1939). Therefore, the first author would like to say that he decided to fly from James Cook University in the City of Townsville in the State of Australia to University of Czernowitz in the City of Czernowitz in the State of Ukraine to pay his respect to Prof. Joseph Alois Schumpeter's scientific achievements in March, 2015.

The first and second authors were graduated from V. N. Karazin Kharkiv National University in the City of Kharkiv in the State of Ukraine in 1993 and 1999, and would like to comment that our research interest in the economic cycles in the economics science is quite natural, because Prof. Simon Kuznets conducted his scientific work on the cyclical fluctuations in 
the economic systems in the City of Kharkiv in the State of Ukraine in 1915 - 1922, being influenced by the Prof. Joseph Alois Schumpeter research ideas and coming up with the remarkable research results in Kuznets (1930, 1973).

Finally, let us note that this research uses the knowledge on the modeling of the electromagnetic field distributions in the microwave resonators, which is described in our book on the nonlinearities in the microwave superconductivity in Ledenyov $D O$, Ledenyov $V O$ (2015a).

*E-mail: $\quad$ dimitri.ledenyov@my.jcu.edu.au , ledenyov@univer.kharkov.ua . 


\section{References:}

\section{Economics Science, Finance Science, Economic History Science:}

1. Joseph Penso de la Vega 1668, 1996 Confusión de Confusiones re-published by John Wiley and Sons Inc USA.

2. Mortimer Th 1765 Every man his own broker 4th edition London UK.

3. Bagehot W 1873, 1897 Lombard Street: A description of the money market Charles Scribner's Sons New York USA.

4. von Böhm-Bawerk E 1884, 1889, 1921 Capital and interest: History and critique of interest theories, positive theory of capital, further essays on capital and interest Austria; 1890 Macmillan and Co Smart W A (translator) London UK http://files.libertyfund.org/files/284/0188_Bk.pdf .

5. Hirsch M 1896 Economic principles: A manual of political economy The Russkin Press Pty Ltd 123 Latrobe Street Melbourne Australia.

6. Bachelier L 1900 Theorie de la speculation Annales de l'Ecole Normale Superieure Paris France vol 17 pp $21-86$.

7. Schumpeter J A 1906 Über die mathematische methode der theoretischen ökonomie ZfVSV Austria.

8. Schumpeter J A 1933 The common sense of econometrics Econometrica.

9. Schumpeter J A 1911; 1939, 1961 Theorie der wirtschaftlichen entwicklung; The theory of economic development: An inquiry into profits, capital, credit, interest and the business cycle Redvers Opie (translator) OUP New York USA.

10. Schumpeter J A 1939 Business cycle McGraw-Hill New York USA.

11. Schumpeter J A 1947 The creative response in economic history Journal of Economic History vol 7 pp 149 - 159.

12. Slutsky E E 1910 Theory of marginal utility M Sc Thesis Vernadsky National Library Kiev Ukraine.

13. Slutsky E E 1915 Sulla teoria sel bilancio del consumatore Giornale degli economisti e rivista di statistica $\mathbf{5 1}$ no 1 pp 1 - 26 Italy.

14. Slutsky E E 1923 On calculation of state revenue from emission of paper money Local Economy 2 pp 39 - 62 Kiev Ukraine.

15. von Mises L 1912 The theory of money and credit Ludwig von Mises Institute Auburn Alabama USA

http://mises.org/books/Theory_Money_Credit/Contents.aspx . 
16. Ellis H, Metzler L (editors) 1949 Readings in the theory of international trade Blakiston Philadelphia USA.

17. Friedman M (editor) 1953 Essays in positive economics Chicago University Press Chicago USA.

18. Baumol W 1957 Speculation, profitability, and stability Review of Economics and Statistics 39 pp $263-271$.

19. Debreu G 1959 Theory of value Cowles Foundation Monograph vol 17 John Wiley \& Sons Inc New York USA.

20. Dodd N 2014 The social life of money Princeton University Press NJ USA ISBN: 9780691141428 pp $1-456$.

\section{Juglar Economic Cycle:}

21. Juglar C 1862 Des crises commerciales et de leur retour périodique en France en Angleterre et aux États-Unis Guillaumin Paris France.

22. Schumpeter J A 1939 Business cycle McGraw-Hill New York USA.

23. Grinin L E, Korotayev A V, Malkov S Y 2010 A mathematical model of Juglar cycles and the current global crisis in History \& Mathematics Grinin L, Korotayev A, Tausch A (editors) URSS Moscow Russian Federation.

\section{Kondratiev Economic Cycle:}

24. Kondratieff N D 1922 The world economy and its trends during and after war Regional branch of state publishing house Vologda Russian Federation.

25. Kondratieff N D 1925 The big cycles of conjuncture The problems of conjuncture pp $28-79$.

26. Kondratieff N D 1926 Die langen wellen der konjunktur Archiv fuer Sozialwissenschaft und Sozialpolitik 56 (3) pp 573 - 609.

27. Kondratieff N D 1928 The big cycles of conjuncture Institute of Economics RANION Moscow Russian Federation.

28. Kondratieff N D, Stolper W F 1935 The long waves in economic life Review of Economics and Statistics The MIT Press 17 (6) pp 105 - 115 doi:10.2307/1928486 JSTOR 1928486.

29. Kondratieff N D 1984 The Long wave cycle Richardson \& Snyder New York USA.

30. Kondratieff N D 2002 The big cycles of conjuncture and theory of forecast Economics Moscow Russian Federation.

31. Barr K 1979 Long waves: A selective annotated bibliography Review 2 (4) pp 675 - 718. 
32. Cleary M N, Hobbs G D 1983 The fifty year cycle: A look at the empirical evidence in Long Waves in the World Economy Freeman $\mathrm{Chr}$ (editor) Butterworth London UK pp $164-182$.

33. Bieshaar H, Kleinknecht A 1984 Kondratieff long waves in aggregate output? An econometric test Konjunkturpolitik 30 (5) pp 279 - 303.

34. Berry B J L 1991 Long wave rhythms in economic development and political behavior Johns Hopkins University Press Baltimore MD USA.

35. Diebolt C, Doliger C 2006 Economic cycles under test: A spectral analysis in Kondratieff Waves, Warfare and World Security Devezas T C (editor) IOS Press Amsterdam The Netherlands pp $39-47$.

36. Eklund K 1980 Long waves in the development of capitalism? Kyklos 33 (3) pp 383 - 419.

37. Forrester J W 1978 Innovation and the economic long wave MIT System Dynamics Group Working Paper Massachusetts Institute of Technology Cambridge USA.

38. Forrester J W 1981 The Kondratieff cycle and changing economic conditions MIT System Dynamics Group Working Paper Massachusetts Institute of Technology Cambridge USA.

39. Forrester J W 1985 Economic conditions ahead: Understanding the Kondratieff wave Futurist 19 (3) pp $16-20$.

40. Freeman C 1987 Technical innovation, diffusion, and long cycles of economic development in The long-wave debate Vasko T (editor) Springer Berlin Germany pp 295-309.

41. Freeman C, Louçã F 2001 As time goes by: From the industrial revolutions to the information revolution Oxford University Press Oxford UK.

42. Garvy G 1943 Kondratieff's theory of long cycles Review of Economic Statistics 25 (4) pp $203-220$.

43. Glismann H H, Rodemer H, Wolter W 1983 Long waves in economic development: Causes and empirical evidence in Long Waves in the World Economy Freeman Chr (editor) Butterworth London UK pp 135 - 163.

44. Goldstein J 1988 Long cycles: Prosperity and war in the modern age Yale University Press New Haven CT USA.

45. Kuczynski Th 1978 Spectral analysis and cluster analysis as mathematical methods for the periodization of historical processes: Kondratieff cycles - Appearance or reality? Proceedings of the Seventh International Economic History Congress vol 2 International Economic History Congress Edinburgh UK pp 79-86. 
46. Kuczynski Th 1982 Leads and lags in an escalation model of capitalist development: Kondratieff cycles reconsidered Proceedings of the Eighth International Economic History Congress vol B3 International Economic History Congress Budapest Hungary pp 27.

47. Linstone H A 2006 The information and molecular ages: Will K-waves persist? Kondratieff Waves, Warfare and World Security edited by Devezas T C IOS Press Amsterdam The Netherlands pp $260-269$.

48. Mandel E 1980 Long waves of capitalist development Cambridge University Press Cambridge UK.

49. Metz R 1992 Re-examination of long waves in aggregate production series New Findings in Long Wave Research Kleinknecht A, Mandel E, Wallerstein I (editors) St. Martin's New York USA pp $80-119$.

50. Metz R 1998 Langfristige wachstumsschwankungen - Trends, zyklen, strukturbrüche oder zufall Kondratieffs Zyklen der Wirtschaft. An der Schwelle neuer Vollbeschäftigung? Thomas H, Nefiodow L A, Herford (editors) pp 283 - 307.

51. Metz R 2006 Empirical evidence and causation of Kondratieff cycles Kondratieff Waves, Warfare and World Security Devezas $\mathrm{T}$ C (editor) IOS Press Amsterdam The Netherlands pp $91-99$.

52. Modelski G 2001 What causes K-waves? Technological Forecasting and Social Change 68 pp $75-80$.

53. Modelski G 2006 Global political evolution, long cycles, and K-waves Kondratieff Waves, Warfare and World Security Devezas $\mathrm{T}$ C (editor) IOS Press Amsterdam The Netherlands pp $293-302$.

54. Modelski G, Thompson W R 1996 Leading sectors and world politics: The co-evolution of global politics and economics University of South Carolina Press Columbia SC USA.

55. Summers L H 1986 Some skeptical observations on real business cycle theory Federal Reserve Bank of Minneapolis Quarterly Review 10 pp 23 - 27.

56. Papenhausen Ch 2008 Causal mechanisms of long waves Futures 40 pp 788 - 794.

57. Perez C 2002 Technological revolutions and financial capital - The dynamics of bubbles and golden ages Edward Elgar Cheltenhem UK.

58. Rennstich J K 2002 The new economy, the leadership long cycle and the nineteenth K-wave Review of International Political Economy 9 pp 150 - 182.

59. Rostow W W 1975 Kondratieff, Schumpeter and Kuznets: Trend periods revisited Journal of Economic History 25 (4) pp 719 - 753. 
60. Rumyantseva S Yu 2003 Long waves in economics: Multifactor analysis St. Petersburg University Publishing House St. Petersburg Russian Federation.

61. Silberling N J 1943 The dynamics of business: An analysis of trends, cycles, and time relationships in American economic activity since 1700 and their bearing upon governmental and business policy McGraw-Hill New York USA.

62. Solomou S 1989 Phases of economic growth, 1850-1973: Kondratieff waves and Kuznets swings Cambridge University Press Cambridge UK.

63. Thompson W 2007 The Kondratieff wave as global social process in World System History, Encyclopedia of Life Support Systems Modelski G (editor) EOLSS Publishers Oxford UK http://www.eolss.net.

64. Tinbergen J 1981 Kondratiev cycles and so-called long waves: The early research Futures $\mathbf{1 3}$ (4) pp $258-263$.

65. Tylecote A 1992 The long wave in the world economy Routledge London UK.

66. Van der Zwan A 1980 On the assessment of the Kondratieff cycle and related issues in Prospects of Economic Growth Kuipers S K, Lanjouw G J (editors) North-Holland Oxford UK pp $183-222$.

67. Van Duijn J J 1979 The long wave in economic life De Economist 125 (4) pp 544 - 576.

68. Van Duijn J J 1981 Fluctuations in innovations over time Futures 13(4) pp 264 - 275.

69. Van Duijn J J 1983 The long wave in economic life Allen and Unwin Boston MA USA.

70. Van Ewijk C 1982 A spectral analysis of the Kondratieff cycle Kyklos 35 (3) pp $468-499$.

71. Wallerstein I 1984 Economic cycles and socialist policies Futures 16 (6) pp 579 - 585.

72. Zarnowitz V 1985 Recent work on business cycles in historical perspective: Review of theories and evidence Journal of Economic Literature $\mathbf{2 3}$ pp $523-580$.

73. Korotayev A V, Tsirel S V 2010 A spectral analysis of world GDP dynamics: Kondratieff waves, Kuznets swings, Juglar and Kitchin cycles in global economic development, and the 2008-2009 economic crisis Structure and Dynamics vol 4 issue 1 pp 1 - 55 http://www.escholarship.org/uc/item/9jv108xp .

74. Cooley Th (editor) 1995 Frontiers of business cycle research Princeton University Press USA ISBN 0-691-04323-X.

\section{Kitchin Economic Cycle:}

75. Kitchin J 1923 Cycles and trends in economic factors Review of Economics and Statistics The MIT Press 5 (1) pp 10 - 16 doi:10.2307/1927031 JSTOR 1927031. 


\section{Kuznets Economic Cycle:}

76. Kuznets S 1924 Economic system of Dr. Schumpeter M. Sc. Thesis under Prof. Wesley Clair Mitchell Columbia University NY USA.

77. Kuznets S 1930 Secular movements in production and prices Ph. D. Thesis under Prof. Wesley Clair Mitchell Columbia University NY USA.

78. Kuznets S 1930 Secular movements in production and prices. Their nature and their bearing upon cyclical fluctuations Houghton Mifflin Boston USA.

79. Kuznets S 1937 National income and capital formation, 1919 - 1935.

80. Kuznets S 1941 National income and its composition, 1919 - 1938.

81. Kuznets S March 1955 Economic growth and income inequality American Economic Review 45 pp $1-28$.

82. Kuznets S 1963 Quantitative aspects of the economic growth of nations, VIII: The distribution of income by size Economic Development and Cultural Change 11 pp 1 - 92.

83. Kuznets S 1966 Modern economic growth: Rate, structure, and spread.

84. Kuznets S 1968 Toward a theory of economic growth, with reflections on the economic growth of modern nations.

85. Kuznets S 1971 Economic growth of nations: Total output and production structure.

86. Kuznets S 1973 Population, capital and growth.

87. Kuznets S 1973 Modern economic growth: Findings and reflections American Economic Review 63 pp 247 - 58.

88. Abramovitz M 1961 The nature and significance of Kuznets cycles Economic Development and Cultural Change 9 (3) pp 225 - 248.

89. Abramovitz M March 1986 Simon Kuznets 91901 - 1985) The Journal of Economic History vol 46 no 1 pp $241-246$.

90. Lundberg E 1971 Simon Kuznets contributions to economics The Swedish Journal of Economics 73 (4) pp 444 - 459 DOI:10.2307/3439225, JSTOR 3439225.

91. Hozelitz B F January 1983 Bibliography of Simon Kuznets Economic Development and Cultural Change vol 31 no 2 pp 433 - 454.

92. Ben-Porath Y April 1988 Simon Kuznets in person and in writing Economic Development and Cultural Change vol 36 no 3 pp 435 - 447.

93. Street J H June 1988 The contribution of Simon S. Kuznets to institutionalist development theory Journal Economic Issues vol 22 no 2 pp 499 - 509.

94. Kapuria-Foreman V, Perlman M November 1995 An economic historian's economist: Remembering Simon Kuznets The Economic Journal 105 pp 1524 - 1547. 
95. Fogel R W 2000 Simon S. Kuznets: April 30, 1901 - July 9, 1985 NBER Working Paper no W7787 NBER USA.

96. Fogel R W, Fogel E M, Guglielmo M, Grotte N 2013 Political arithmetic: Simon Kuznets and the empirical tradition in economics University of Chicago Press Chicago USA ISBN 0-226-25661-8.

97. Syed M K, Mohammad M J 2004 Revisiting Kuznets hypothesis: An analysis with time series and panel data Bangladesh Development Studies 30 (3-4) pp 89 - 112.

98. Diebolt C, Doliger C 2008 New international evidence on the cyclical behaviour of output: Kuznets swings reconsidered. Quality \& quantity. International Journal of Methodology 42 (6) pp $719-737$.

99. Wikipedia Simon Kuznets Economist Wikipedia USA www.wikipedia.org.

\section{Accurate Characterization of Properties of Economic Cycles:}

100. George H 1881, 2009 Progress and poverty Kegan Paul USA; reissued by Cambridge University Press Cambridge UK ISBN 978-1-108-00361-2.

101. Schumpeter J A 1939 Business cycle McGraw-Hill New York USA.

102. Burns A F, Mitchell W C 1946 Measuring business cycles National Bureau of Economic Research New York USA.

103. Dupriez L H 1947 Des mouvements economiques generaux vol 2 pt 3 Institut de Recherches Economiques et Sociales de 1'Universite de Louvain Belgium.

104. Samuelson P A 1947 Foundations of economic analysis Harvard University Press Cambridge MA USA.

105. Hicks J R 1950 A contribution to the theory of the trade cycle Oxford University Press Oxford UK.

106. Inada K, Uzawa H 1972 Economical development and fluctuations Iwanami Tokyo Japan.

107. Bernanke B S 1979 Long-Term Commitments, Dynamic Optimization, and the Business Cycle Ph. D. Thesis Department of Economics Massachusetts Institute of Technology USA.

108. Marchetti C 1980 Society as a learning system: Discovery, invention, and innovations cycles revisited Technological Forecast and Social Change 18 pp 257 - 282.

109. Kleinknecht A 1981 Innovation, accumulation, and crisis: Waves in economic development? Review 4 (4) pp 683 - 711.

110. Dickson D 1983 Technology and cycles of boom and bust Science 219 (4587) pp $933-936$. 
111. Hodrick R J, Prescott E C 1997 Postwar U.S. business cycles: An empirical investigation Journal of Money, Credit, and Banking vol 29 no 1 pp 1 - 16.

112. Baxter M, King R G 1999 Measuring business cycles: Approximate band-pass filters for economic time series Review of Economics and Statistics 81 (4) pp 575 - 593.

113. Kim Ch-J, Nelson Ch 1999 Has the U.S. economy become more stable? A Bayesian approach based on a Markov-switching model of the business cycle Review of Economics and Statistics.

114. McConnell M, Pérez-Quirós G 2000 Output fluctuations in the United States: What has changed since the early 1980s? American Economic Review.

115. Devezas T C, Corredine J T 2001 The biological determinants of long-wave behavior in socioeconomic growth and development Technological Forecasting \& Social Change $\mathbf{6 8}$ pp $1-57$.

116. Devezas T C, Corredine J T 2002 The nonlinear dynamics of technoeconomic systems. An informational interpretation Technological Forecasting \& Social Change 69 pp $317-357$.

117. Devezas T C (editor) 2006 Kondratieff Waves, Warfare and World Security IOS Press Amsterdam The Netherlands.

118. Arnord L 2002 Business cycle theory Oxford University Press Oxford UK 2002.

119. Stock J, Watson M 2002 Has the business cycle changed and why? NBER Macroeconomics Annual NBER USA.

120. Helfat C E, Peteraf M A 2003 The dynamic resource-based view: Capability life cycles Strategic Management Journal 24 (10) pp 997 - 1010.

121. Sussmuth B 2003 Business cycles in the contemporary World Springer Berlin Heidelberg Germany.

122. Hirooka M 2006 Innovation dynamism and economic growth: A nonlinear perspective Edward Elgar Cheltenham UK Northampton MA USA.

123. Kleinknecht A, Van der Panne G 2006 Who was right? Kuznets in 1930 or Schumpeter in 1939? in Kondratieff Waves, Warfare and World Security Devezas T C (editor) IOS Press Amsterdam The Netherlands pp 118 - 127.

124. Jourdon $\mathrm{Ph} 2008 \mathrm{La}$ monnaie unique Europeenne et son lien au developpement economique et social coordonne: une analyse cliometrique Thèse Universite Montpellier France.

125. Taniguchi M, Bando M, Nakayama A 2008 Business cycle and conserved quantity in economics Journal of the Physical Society of Japan vol 77 no 11. 
126. Drehmann M, Borio C, Tsatsaronis K 2011 Anchoring countercyclical capital buffers: The role of credit aggregates International Journal of Central Banking vol 7 no 4 pp $189-240$.

127. Iyetomi H, Nakayama Y, Yoshikawa H, Aoyama H, Fujiwara Y, Ikeda Y, Souma W 2011 Journal of the Japanese and International Economies 25246.

128. Ikeda Y, Aoyama H, Fujiwara Y, Iyetomi H, Ogimoto K, Souma W and Yoshikawa H 2012 Coupled oscillator model of the business cycle with fluctuating goods markets Progress of Theoretical Physics Supplement no 194 pp 111 - 121.

129. Swiss National Bank 2012 Swiss National Bank financial stability report 2012 http://www.snb.ch/en/mmr/reference/stabrep_2012/source/stabrep_2012.en.pdf .

130. Swiss National Bank 2013 Countercyclical capital buffer: Proposal of the Swiss National Bank and decision of the Federal Council http://www.snb.ch/en/mmr/reference/pre_20130213/source/pre_20130213.en.pdf .

131. Uechi L, Akutsu T 2012 Conservation laws and symmetries in competitive systems Progress of Theoretical Physics Supplement no 194 pp 210 - 222.

132. Central Banking Newsdesk 2013 Swiss board member supports counter-cyclical capital buffer

http://www.centralbanking.com/central-banking/speech/2203857/swiss-board-membersupportscountercyclical-capital-buffer .

133. Union Bank of Switzerland 2013 UBS outlook Switzerland http://www.ubs.com/global/en/wealth_management/wealth_management_research/ubs_outlo ok_ch.html .

134. Wikipedia 2015 Business cycle Wikimedia California USA www.wikimedia.org.

\section{Disruptive Innovation in Terms of Economics Science:}

135. Schumpeter J A 1911; 1939, 1961 Theorie der wirtschaftlichen entwicklung; The theory of economic development: An inquiry into profits, capital, credit, interest and the business cycle Redvers Opie (translator) OUP New York USA.

136. Schumpeter J A 1939 Business cycle McGraw-Hill New York USA.

137. Schumpeter J A 1947 The creative response in economic history Journal of Economic History vol 7 pp $149-159$.

138. Solow R H August 1957 Technical change and the aggregate production function Review of Economics and Statistics 39 pp 214 - 231. 
139. Christensen C M June 16, 1977 Fatal attraction: The dangers of too much technology Computerworld Leadership Series pp $3-11$.

140. Christensen C M Fall 1992a Exploring the limits of the technology S-curve, Part 1: Component Technologies Production and Operations Management 1 pp 334 - 357.

141. Christensen C M Fall 1992b Exploring the limits of the technology S-curve, Part 2: Architectural technologies Production and Operations Management 1 pp 358 - 366.

142. Bower J L, Christensen C M January February 1995 Disruptive technologies: Catching the wave Harvard Business Review 73 no 1 pp 43 - 53.

143. Bower J L, Christensen C M 1997 Disruptive technologies: Catching the wave in Seeing differently: Insights on innovation Brown J S (editor) Harvard Business School Press Boston MA USA.

144. Christensen C M 1997 The innovator's dilemma: When new technologies cause great firms to fail Harvard Business School Press Boston MA USA.

145. Christensen C M, Armstrong E G Spring 1998 Disruptive technologies: A credible threat to leading programs in continuing medical education? Journal of Continuing Education in the Health Professions 69 no 80 pp 69 - 80.

146. Christensen C M 1998 The evolution of innovation in Technology management handbook Dorf R (editor) CRC Press Boca Raton FL USA.

147. Christensen C M December 1998 Disruptive technologies: Catching the wave TN Harvard Business School Teaching Note 699 - 125.

148. Christensen C M, Cape E G December 1998 Disruptive technology a heartbeat away: Ecton, Inc Harvard Business School Case 699 - 018.

149. Christensen C M April 1999a Value networks and the impetus to change: Managing innovation: Overview teaching note for module 1 Harvard Business School Teaching Note $699-163$.

150. Christensen C M April 1999b Finding new markets for new and disruptive technologies: Managing innovation, overview teaching note for module 2 Harvard Business School Teaching Note 699 - 164.

151. Christensen C M April 1999c Teradyne: The Aurora project \& Teradyne: Corporate management of disruptive change, TN Harvard Business School Teaching Note 399 - 087.

152. Christensen C M, Dann J June 1999 Processes of strategy definition and implementation, The Harvard Business School Background Note 399 - 179. 
153. Bower J L, Christensen C M 1999 Disruptive technologies: Catching the wave Ch 29 in The entrepreneurial venture $2^{\text {nd }}$ edition Sahlman W A, Stevenson H H, Roberts M J, Bhide A V pp 506 - 520 Harvard Business School Press Boston MA USA.

154. Christensen C M 1999a Innovation and the general manager Irwin McGraw-Hill Homewood IL USA.

155. Christensen C M 1999b Impact of disruptive technologies in telecommunications in Bringing PC economies to the telecommunications industry PulsePoint Communications.

156. Christensen C M, Tedlow R S January February 2000 Patterns of disruption in retailing Harvard Business Review 78 no 1 pp 42 - 45.

157. Christensen C M, Donovan T March 2000 Disruptive technology a heartbeat away: Ecton, Inc TN Harvard Business School Teaching Note 600 - 129.

158. Christensen C M, Overdorf M March April 2000 Meeting the challenge of disruptive change Harvard Business Review 78 no 2 pp $66-76$.

159. Christensen C M, Bohmer R M J, Kenagy J September October 2000 Will disruptive innovations cure health care? Harvard Business Review 78 no 5 pp $102-117$.

160. Christensen C M, Craig Th, Hart S March April 2001 The great disruption Foreign Affairs $\mathbf{8 0}$ no 2.

161. Christensen C M Summer 2001 Assessing your organization's innovation capabilities Leader to Leader no 21 pp 27 - 37.

162. Christensen C M, Milunovich S March 2002 Technology strategy: The theory and application of the Christensen model Merrill Lynch Report Series.

163. Bass M J, Christensen C M April 2002 The future of the microprocessor business IEEE Spectrum 39 no 4.

164. Anthony S D, Roth E A, Christensen C M April 2002 The policymaker's dilemma: The impact of government intervention on innovation in the telecommunications industry Harvard Business School Working Paper no 02 - 075.

165. Kenagy J, Christensen C M May 2002 Disruptive innovation: A new diagnosis for health care's 'Financial flu' Healthcare Financial Management pp 62 - 66.

166. Christensen C M, Johnson M W, Rigby D K Spring 2002 Foundations for growth: How to identify and build disruptive new businesses MIT Sloan Management Review 43 no 3.

167. Kenagy J W, Christensen C M 2002 Disruptive innovation - New diagnosis and treatment for the systemic maladies of healthcare World Markets Series Business Briefing Global Healthcare 2002 pp $14-17$.

168. Christensen C M June 2002 The rules of innovation Technology Review. 
169. Hart S L, Christensen C M Fall 2002 The great leap: Driving innovation from the base of the global pyramid MIT Sloan Management Review 44 no 1 pp 51 - 56.

170. Christensen C M, Verlinden M, Westerman G November 2002 Disruption, disintegration, and the dissipation of differentiability Industrial and Corporate Change $\mathbf{1 1}$ no 5 pp $955-993$.

171. Christensen C M 2003 The opportunity and threat of disruptive technologies Harvard Business School Publishing Class Lecture HBSP Product Number 1482C Boston MA USA.

172. Shah Ch D, Brennan T A, Christensen C M April 2003 Interventional radiology: Disrupting invasive medicine.

173. Christensen C M March April 2003 Beyond the innovator's dilemma Strategy \& Innovation 1 no 1.

174. Christensen C M, Raynor M E 2003 The innovator's solution: Creating and sustaining successful growth Harvard Business School Press Boston MA USA.

175. Burgelman R A, Christensen C M, Wheelwright S C 2003 Strategic management of technology and innovation $4^{\text {th }}$ edition McGraw-Hill Irwin USA.

176. Christensen C M, Anthony S D January February 2004 Cheaper, faster, easier: Disruption in the service sector Strategy \& Innovation 2 no 1.

177. Christensen C M, Anthony S D, Roth E A 2004 Seeing what's next: Using the theories of innovation to predict industry change Harvard Business School Press Boston MA USA.

178. Christensen C M January 2006 The ongoing process of building a theory of disruption Journal of Product Innovation Management 23 pp 39 - 55.

179. Christensen C M, Baumann H, Ruggles R, Sadtler Th M December 2006 Disruptive innovation for social change Harvard Business Review 84 no 12.

180. Christensen C M, Horn M B, Johnson C W 2008 Disrupting class: How disruptive innovation will change the way the World learns McGraw-Hill USA.

181. Christensen C M, Grossman J H, Hwang J 2009 The innovator's prescription: A disruptive solution for health care McGraw-Hill USA.

182. Dyer J H, Gregersen H B, Christensen C M December 2009 The innovator's DNA Harvard Business Review 87 no 12.

183. Christensen C M, Donovan T May 2010 Disruptive IPOs? WR Hambrecht \& Co Harvard Business School Case 610-065.

184. Dyer J H, Gregersen H B, Christensen C M 2011 The innovator's DNA: Mastering the five skills of disruptive innovators Harvard Business Press Boston MA USA. 
185. Christensen C M, Talukdar Sh, Alton R, Horn M B Spring 2011 Picking green tech's winners and losers Stanford Social Innovation Review USA.

186. Christensen C M, Wang D, van Bever D October 2013 Consulting on the cusp of disruption Harvard Business Review 91 no 10 pp 106 - 114.

187. Bhattacharya S, Ritter J R 1983 Innovation and communication: Signaling with partial disclosure Review of Economic Studies $\mathbf{5 0}$ pp 331 - 346.

188. Scherer F M 1984 Innovation and growth: Schumpeterian perspectives MIT Press Cambridge MA USA.

Probability Theory, Statistics Theory, Spectrum Analysis Theory, Brownian Movement Theory, Diffusion Theory, Chaos Theory, Information Communication Theory in Econometrics and Econophysics Sciences:

189. Huygens 1657 De ratiociniis in aleae ludo (On calculations in games of chance).

190. Bernoulli J 1713 Ars conjectandi (The art of guessing).

191. Bernoulli D 1738, 1954 Specimen theoria novae de mensura sortis Commentarii Academiae Scientiarium Imperialis Petropolitanae Petropoli vol 5 pp 175 - 192; Exposition of a new theory on the measurements of risk Sommer L (translator) Econometrica vol 22 pp $23-36$.

192. De Moivre 1730 Miscellanea analytica supplementum (The analytic method).

193. Fourier J-B J 1807-1822, 1878, 2009 Théorie Analytique de la Chaleur Firmin Didot, Cambridge University Press ISBN 978-1-108-00178-6, ISBN 978-1-108-00180-9.

194. Fourier J-B J 1824 Mémoires de l'Académie Royale des Sciences de l'Institut de France VII pp $570-604$

http://www.academie-

sciences.fr/activite/archive/dossiers/Fourier/Fourier_pdf/Mem1827_p569_604.pdf .

195. De Laplace 1812 Théorie analytique des probabilities Paris France.

196. Bunyakovsky V Ya 1825 Rotary motion in a resistant medium of a set of plates of constant thickness and defined contour around an axis inclined with respect to the horizon Ph D Thesis no 1 under Prof. Augustin - Louis Cauchy supervision École Polytechnique Paris France.

197. Bunyakovsky V Ya 1825 Determination of the radius-vector in elliptical motion of planets Ph D Thesis no 2 under Prof. Augustin - Louis Cauchy supervision École Polytechnique Paris France.

198. Bunyakovsky V Ya 1825 Heat propagation in solids $P h \quad D$ Thesis no 3 under Prof. Augustin - Louis Cauchy supervision École Polytechnique Paris France. 
199. Bunyakovsky $\mathrm{V}$ Ya 1846 Foundations of the mathematical theory of probability St. Petersburg Russian Federation.

200. Connor J J, Robertson E F (July) 2000 Viktor Yakovlevich Bunyakovsky (December 16, 1804 - December 12, 1889) School of Mathematics and Statistics University of St Andrews Scotland UK

http://www-history.mcs.st-andrews.ac.uk/Biographies/Bunyakovsky.html .

201. V Ya Bunyakovsky International Conference (August 20 - 21) 2004 Private communications with conference participants on V Ya Bunyakovsky's mathematical theory of probability and its applications in econophysics and econometrics during a tour to Town of Bar Vinnytsia Region Ukraine V Ya Bunyakovsky International Conference Institute of Mathematics of National Academy of Sciences of Ukraine (NASU) Kyiv Ukraine www.imath.kiev.ua/ syta/bunyak .

202. Chebyshev P L 1846 An experience in the elementary analysis of the probability theory Crelle's Journal fur die Reine und Angewandte Mathematik.

203. Chebyshev P L 1867 Des valuers moyennes Journal de Math'ematics Pures et Appliqu'ees vol 12 pp 177 - 184.

204. Chebyshev P L 1891 Sur deux theoremes relatifs aux probabilities Acta Mathematica vol 14.

205. Chebyshev P L 1936 Theory of probability: Lectures given in 1879 and 1880 Lyapunov A N (lecture notes writer) Krylov A N (editor) Moscow - St Petersburg Russian Federation.

206. Markov A A 1890 On one problem by D I Mendeleev Zapiski Imperatorskoi Akademii Nauk SPb 62 pp $1-24$.

207. Markov A A 1899 Application des functions continues au calcul des probabilit'es Kazan Bulletin 9 (2) pp 29 - 34 Russian Federation.

208. Markov A A 1900, 1912, 1913 Calculation of probabilities St Petersburg Russian Federation; Wahrscheinlichkeits-Rechnung Teubner Leipzig-Berlin Germany; $3^{\text {rd }}$ edition St Petersburg Russian Federation.

209. Markov A A 1906 Extension of law of big numbers on variables, depending from each other Izvestiya Fiziko-Matematicheskogo Obschestva pri Kazanskom Universitete $2^{\text {nd }}$ series vol 15 (94) pp 135 - 156 Russian Federation.

210. Markov A A 1907, 1910 Research on fine case of depending trials Izvestiya Akademii Nauk $S P b 6^{\text {th }}$ series vol 1 (93) pp 61 - 80; Recherches sur un cas remarquable d'epreuves dependantes Acta Mathematica 33 pp 87 - 104 Stockholm Sweden. 
211. Markov A A 1908, 1912, 1971 Extension of limit theorems of calculation of probabilities to sum of variables, connected in chain Zapiski Akademii Nauk po Fiziko-Matematicheskomu Otdeleniyu $8^{\text {th }}$ series vol 25 (3); Ausdehnung der Satze uber die Grenzwerte in der Wahrscheinlichkeitsrechnung auf eine Summe verketteter Grossen Liebmann H (translator) in Wahrscheinlichkeitsrechnung Markov A A (author) pp 272 - 298 Teubner B G Leipzig Germany; Extension of the limit theorems of probability theory to a sum of variables connected in a chain Petelin S (translator) in Dynamic probabilities systems Howard R A (editor) vol 1 pp 552 - 576 John Wiley and Sons Inc New York USA.

212. Markov A A 1910 Research on common case of trials, connected in chain Zapiski Akademii Nauk po Fiziko-Matematicheskomu Otdeleniyu $8^{\text {th }}$ series vol 25 (93) Russian Federation.

213. Markov A A 1911 On one case of trials, connected in complex chain Izvestiya Akademii Nauk $S P b 6^{\text {th }}$ series vol 5 (93) pp 171 - 186 Russian Federation.

214. Markov A A 1912 On trials of connected in chain unobserved events Izvestiya Akademii Nauk $S P b 6^{\text {th }}$ series vol 6 (98) pp $551-572$ Russian Federation.

215. Markov A A 1913 Example of statistical research on text of "Eugene Onegin", illustrating interconnection of trials in chain Izvestiya Akademii Nauk SPb $6^{\text {th }}$ series vol 7 (93) pp 153 - 162 Russian Federation.

216. Fisher I 1892 Mathematical investigations in the theory of value and prices Transactions of the Connecticut Academy 9 pp 1 - 124.

217. Einstein A 1905 On the movement of small particles suspended in a stationary liquid demanded by the molecular-kinetic theory of heat Annalen der Physik 17 pp 549 - 560.

218. Einstein A 1956 Investigation on the theory of the Brownian motion Furth R (editor) Dover New York USA.

219. Einstein A, Smolukhovsky M 1936 Brownian movement: Collection of research papers ONTI Moscow Russian Federation.

220. Slutsky E E 1910 Theory of marginal utility M Sc Thesis Vernadsky National Library Kiev Ukraine.

221. Slutsky E E 1912 Theory of correlation and elements of study about distribution curves Kiev Commerce Institute Bulletin 16 pp 1 - 208 Kiev Ukraine.

222. Slutsky E E 1913 On the criterion of goodness of fit of the regression lines and the best method of fitting them to the data Journal Royal Statistics Society vol 77 part I pp $8-84$. 
223. Slutsky E E 1914 Sir William Petty: Short overview of his economic visions with attachment of his several important research works Kiev Commerce Institute Bulletin 18 pp 5-48 Kiev Ukraine.

224. Slutsky E E 1915 Sulla teoria sel bilancio del consumatore Giornale degli economisti e rivista di statistica 51 no 1 pp 1 - 26 Italy.

225. Slutsky E E 1922a Statistics and mathematics. Review of Kaufman Statistics Bulletin 3 4 pp $104-120$.

226. Slutsky E E 1922b To the question of logical foundations of probability calculation Statistics Bulletin 9 - 12 pp 13 - 21.

227. Slutsky E E 1923a On the some patterns of correlation connection and the systematic error of correlation coefficient Statistics Bulletin 1 - 3 pp 31 - 50.

228. Slutsky E E 1923b On a new coefficient of mean density of population Statistics Bulletin 4 - 6 pp 5 - 19.

229. Slutsky E E 1923c On calculation of state revenue from emission of paper money Local Economy 2 pp 39 - 62 Kiev Ukraine.

230. Slutsky E E 1925a On the law of large numbers Statistics Bulletin 7 - 9 pp 1 - 55.

231. Slutsky E E 1925b Ueber stochastische Asymptoten und Grenzwerte Metron Padova Italy vol 5 no 3 pp $3-89$.

232. Slutzhi E E 1926 Ein Beitrag zur Formal-praxeologischen Grundlegung der Oekonomik Ann de la classe des sci soc-econ Akad Oukrainienne des Sciences Kiev Ukraine vol 4 pp $3-12$.

233. Slutsky E E 1927a The summation of random causes as sources of cyclic processes Problems of Conjuncture (Voprosy Kon'yunktury) vol 3 issue 1 pp 34 - 64 Moscow Russian Federation.

234. Slutzhi E E 1927b Zur Kritik des Bohm-Bawerkschen Wertbegriffs und seiner Lehre von der Messbarkeit des Wertes Schmollers Jb 51 (4) pp 37 - 52.

235. Slutsky E E 1929 Sur l'erreur quadratique mogenne du coefficient de correlation dans le cas des suites des epreuves non independantes Comptes rendus 189 pp 612 - 614.

236. Slutsky E E 1935 To the extrapolation problem in connection with forecast problem Geophysics Journal 5 (3) pp 263 - 277.

237. Slutsky E E 1937a Quelche propositione relative alla teoria delle funzioni aleatorie Giornale dell Istituto Italiano degli Attuari 8 no 2 pp $3-19$.

238. Slutsky E E 1937b The summation of random causes as the source of cyclical processes Econometrica 5 pp 105 - 146. 
239. Slutsky E E 1942, 1999 Autobiography of December 3, 1942 Economics School 5 pp $18-21$.

240. Slutsky E E 1960 Selected research works (Izbrannye trudy) Academy of Sciences of USSR Moscow Russian Federation.

241. Bowley A L 1924 The mathematical groundwork of economic Clarendon Press Oxford UK.

242. Kolmogorov A N 1937 Markov chains with countable many states Bulletin Moscow University 1.

243. Kolmogorov A N 1938 On analytic methods in probability theory in Selected works of Kolmogorov A N vol 2 Probability theory and mathematical statistics Shiryaev A N (editor) Springer Germany.

244. Kolmogorov A N 1947 The contribution of Russian science to the development of probability theory Uchenye Zapiski Moskovskogo Universiteta no 91.

245. Kolmogorov A N 1956 Probability theory in Mathematics: Its contents, methods, and meaning Academy of Sciences USSR vol 2.

246. Kolmogorov A N 1956 Foundations of the theory of probability Chelsea New York USA.

247. Kolmogorov A N 1985 Mathematics and mechanics Selected works vol 1 Nauka Publishing House Moscow Russian Federation.

248. Kolmogorov A N 1986 Probability theory and mathematical statistics Selected works vol 2 Nauka Publishing House Moscow Russian Federation.

249. Allen R G D 1938 Mathematical analysis for economists Macmillan London UK.

250. Cramer H 1940 On the theory of stationary random processes Ann Math vol 41 pp $215-230$.

251. Cramer H 1946 Mathematical methods of statistics Princeton University Press USA.

252. Cramer H, Leadbetter M 1967 Stationary and related stochastic processes. Sample function properties and their applications John Wiley and Sons Inc NY USA.

253. Bemshtein S N 1946 Theory of probability $4^{\text {th }}$ edition Gostehizdat Moscow Russian Federation.

254. Neyman J, Scott E L 1948 Consistent estimates based on partially consistent observations Econometrica 16 pp $1-32$.

255. Shannon C E 1948 A mathematical theory of communication Bell System Technical Journal 27 pp 379 - 423 and pp 623 - 656.

256. Hannan E J 1960 Time series analysis Methuen London.

257. Hannan E J 1970 Multiple time series John Wiley and Sons Inc New York USA. 
258. Mandelbrot B B 1960 The Pareto-Levy law and the distribution of income International Economic Review no 1.

259. Mandelbrot B B 1963a The stable Paretian income distribution when the apparent exponent is near two International Economic Review no 4.

260. Mandelbrot B B 1963b The variation of certain speculative prices Journal of Business vol 36 pp $394-419$.

261. Mandelbrot B B 1965 Une classe de processus stochastiques homothetiques a soi: Application a la loi climatologique de H. E. Hurst Comptes Rendus de l'Academie des Sciences vol 240 pp 3274 - 3277 Paris France.

262. Mandelbrot B B 1967a The variation of some other speculative prices Joural of Business vol 40 pp $393-413$.

263. Mandelbrot B B (April) 1967b Some noises with 1/f spectrum: A bridge between direct current and white noise IEEE Transactions on Information Theory USA.

264. Mandelbrot B B, Taylor H M 1967 On the distribution of stock price difference Operations Research vol 15 no 6 pp 1057 - 1062.

265. Mandelbrot B B, van Ness J W 1968 Fractional Brownian motions, fractional noises and applications SIAM Review vol 10 no 4 pp 422 - 437.

266. Mandelbrot B B 1969 Robustness of the rescaled range R/S in the measurement of noncyclic long-run statistical dependence Water Resources Research vol 5 no 5 pp $967-988$.

267. Mandelbrot B B, Wallis J R 1969 Computer experiments with fractional Gaussian noises I, II, III Water Resources Research vol 5 pp 228 - 267.

268. Mandelbrot B B 1971 When can price be arbitrated efficiently? A limit of the validity of the random walk and martingale models Review of Economics and Statistic vol $\mathbf{5 3}$ pp $225-236$.

269. Mandelbrot B B 1972 Statistical methodology for non-periodic cycles: From the covariance to R/S analysis Annals of Economic and Social Measurement vol 1 no 3 pp $259-290$.

270. Mandelbrot B B 1975a Les objects fractals Flammarion Paris France.

271. Mandelbrot B B 1975b Limit theorems on the self-normalized range for weakly and strongly dependent process Zeitschrift Wahrscheinlichkeitsttheorie und Verwandte Gebiete vol 31 pp $271-285$.

272. Mandelbrot B B 1977 Fractals: Form, chance and dimension W H Freeman San Francisco USA. 
273. Mandelbrot B B 1982 The fractal geometry of nature W H Freeman San Francisco USA.

274. Mandelbrot B B 1997 Fractals and scaling in finance Springer New York USA.

275. Gnedenko B V, Khinchin A Ya 1961 An elementary introduction to the theory of probability Freeman San Francisco USA.

276. Gnedenko B V 1988 The theory of probability Mir Moscow Russian Federation.

277. Shiryaev A N 1961 The problem of the most rapid detection of a disturbance in a stationary process Soviet Mathematical Doklady 2 pp 795 - 799.

278. Shiryaev A N 1963 On optimal methods in quickest detection problems Theory of Probability and its Applications 8 (1) pp $22-46$.

279. Shiryaev A N 1964 On Markov sufficient statistics in non-additive Bayes problems of sequential analysis Theory of Probability and its Applications 9 (4) pp 670 - 686.

280. Shiryaev A N 1965 Some exact formulas in a 'disorder' problem Theory of Probability and its Applications 10 pp 348 - 354.

281. Grigelionis B I, Shiryaev A N 1966 On Stefan's problem and optimal stopping rules for Markov processes Theory of Probability and its Applications 11 pp 541 - 558.

282. Shiryaev A N 1967 Two problems of sequential analysis Cybernetics $\mathbf{3}$ pp $63-69$.

283. Liptser R S, Shiryaev A N 1977 Statistics of random processes Springer-Verlag New York USA.

284. Shiryaev A N 1972 Random processes Moscow State University Press Russian Federation.

285. Shiryaev A N 1973, 1974 Probability, statistics, random processes Moscow State University Press vols 1, 2 Russian Federation.

286. Shiryaev A N 1978, 2008b Optimal stopping rules $1^{\text {st }}$ edition, $3^{\text {rd }}$ edition Springer ISSN 0172-4568 Library of Congress Control Number: 2007934268 Berlin Germany pp $1-217$.

287. Shiryaev A N 1988 Probability Springer-Verlag Berlin Heidelberg Germany.

288. Shiryaev A N 1995 Probability $2^{\text {nd }}$ edition Springer - Verlag ISBN 0-387-94549-0 New York USA pp $1-621$.

289. Shiryaev A N 1998a Foundations of stochastic financial mathematics vol 1 Fazis Scientific and Publishing House Moscow Russian Federation ISBN 5-7036-0044-8 pp $1-492$.

290. Shiryaev A N 1998b Foundations of stochastic financial mathematics vol 2 Fazis Scientific and Publishing House Moscow Russian Federation ISBN 5-7036-0044-8 pp 493 - 1017. 
291. Shiryaev A N 1999 Essentials of stochastic finance: Facts, models, theory Advanced Series on Statistical Science \& Applied Probability vol 3 World Scientific Publishing Co Pte Ltd Kruzhilin N (translator) ISBN 981-02-3605-0 Singapore pp 1 - 834.

292. Shiryaev A N, Spokoiny V G 2000 Statistical experiments and decisions: Asymptotic theory World Scientific Publishing Co Pte Ltd ISBN 9810241011 Singapore pp 1 - 283.

293. Graversen S E, Peskir G, Shiryaev A N 2001 Stopping Brownian motion without anticipation as close as possible to its ultimate maximum Theory of Probability and its Applications 45 pp 125 - 136 MR1810977

http://www.ams.org/mathscinetgetitem?mr=1810977 .

294. Kallsen J, Shiryaev A N 2001 Time change representation of stochastic integrals Theory of Probability and its Applications 46 pp $579 \quad-\quad 585$ MR1978671 http://www.ams.org/mathscinet-getitem?mr=1978671 .

295. Kallsen J, Shiryaev A N 2002 The cumulant process and Esscher's change of measure $\begin{array}{llllllll}\text { Finance } & \text { Stoch } & 6 & \text { pp } & 397 & - & 428 & \text { MR1932378 }\end{array}$ http://www.ams.org/mathscinetgetitem? $\mathrm{mr}=1932378$.

296. Shiryaev A N 2002 Quickest detection problems in the technical analysis of the financial data Proceedings Mathematical Finance Bachelier Congress Paris France (2000) Springer Germany pp 487 - 521 MR1960576

http://www.ams.org/mathscinet-getitem?mr=1960576 .

297. Jacod J, Shiryaev A N 2003 Limit theorems for stochastic processes 2nd edition Grundlehren der Mathematischen Wissenschaften [Fundamental Principles of Mathematical $\begin{array}{lllll}\text { Sciences] } & \mathbf{2 8 8} & \text { Springer } & \text { Berlin } & \text { Germany }\end{array}$ http://www.ams.org/mathscinetgetitem? $\mathrm{mr}=1943877$.

298. Shiryaev A N 2004 Kolmogorov and modern mathematics International Conference at Mathematical Institute named after V A Steklov June 16-21, 2003 Russian Academy of Sciences Moscow Russian Federation ISBN 5-98419-003-6 pp 1 - 195.

299. Shiryaev A N, Grossinho M R, Oliveira P E, Esquível M L (editors) 2006 Stochastic finance Springer Germany ISBN-10:0-387-28262-9 pp 1-364.

300. Peskir G, Shiryaev A N 2006 Optimal stopping and free-boundary problems Lectures in $\begin{array}{lllll}\text { Mathematics } & \text { ETH } & \text { Zürich Birkhäuser } & \text { Switzerland } & \text { MR2256030 }\end{array}$ http://www.ams.org/mathscinet-getitem?mr=2256030 .

301. Feinberg E A, Shiryaev A N 2006 Quickest detection of drift change for Brownian motion in generalized Bayesian and mini-max settings Statistics \& Decisions 24 (4) pp $445-470$. 
302. Kabanov Yu, Lipster R, Stoyanov J 2006 The Shiryaev festschrift: From stochastic calculus to mathematical finance Springer Germany pp $1-668$.

303. du Toit J, Peskir G, Shiryaev A N 2007 Predicting the last zero of Brownian motion with drift Cornell University NY USA pp $1-17$

http://arxiv.org/abs/0712.3415v1.

304. Shiryaev A N 2008a Generalized Bayesian nonlinear quickest detection problems: on Markov family of sucient statistics Mathematical Control Theory and Finance Proceedings of the Workshop of April 10-14 2007 Lisbon Portugal Sarychev A et al (editors) Springer Berlin Germany pp 377 - 386.

305. Eberlein E, Papapantoleon A, Shiryaev A N 2008 On the duality principle in option pricing: Semimartingale setting Finance Stoch 12 pp 265 - 292 http://www.ams.org/mathscinet-getitem?mr=2390191 .

306. Shiryaev A N, Novikov A A 2009 On a stochastic version of the trading rule "Buy and hold" Statistics \& Decisions 26 (4) pp 289 - 302.

307. Eberlein E, Papapantoleon A, Shiryaev A N 2009 Esscher transform and the duality principle for multidimensional semimartingales The Annals of Applied Probability vol 19 no 5 pp 1944 - 1971 http://dx.doi.org/10.1214/09-AAP600 http://arxiv.org/abs/0809.0301v5 .

308. Shiryaev A N, Zryumov P Y 2009 On the linear and nonlinear generalized Bayesian disorder problem (discrete time case) optimality and risk - modern trends in mathematical finance The Kabanov Festschrift Delbaen F et al (editors) Springer Berlin Germany pp $227-235$.

309. Gapeev P V, Shiryaev A N 2010 Bayesian quickest detection problems for some diffusion processes Cornell University NY USA pp 1 - 25 http://arxiv.org/abs/1010.3430v2 .

310. Karatzas I, Shiryaev A N, Shkolnikov M 2011 The one-sided Tanaka equation with drift Cornell University NY USA http://arxiv.org/abs/1108.4069v1 .

311. Shiryaev A N, Zhitlukhin M V 2012 Optimal stopping problems for a Brownian motion with a disorder on a finite interval Cornell University NY USA pp 1 - 10 http://arxiv.org/abs/1212.3709v1 .

312. Zhitlukhin M V, Shiryaev A N 2012 Bayesian disorder detection problems on filtered probability spaces Theory of Probability and Its Applications 57 (3) pp 453 - 470.

313. Feinberg E A, Mandava M, Shiryaev A N 2013 On solutions of Kolmogorov's equations for nonhomogeneous jump Markov processes Cornell University NY USA pp 1 - 15 http://arxiv.org/abs/1301.6998v3 . 
314. Abramowitz M, Stegun I A (editors) 1964 Handbook of mathematical functions National Bureau of Standards Applied Mathematics Series vol 55 USA.

315. Kubilius J 1964 Probabilistic methods in the theory of numbers American Mathematical Society Providence USA.

316. Akhiezer N I, Glazman I M 1966 Theory of linear operators in Hilbert space Nauka Moscow Russian Federation.

317. Lamperti J 1966 Probability Benjamin New York USA.

318. Kai-Lai Chung 1967 Markov chains with stationary transition probabilities SpringerVerlag New York USA.

319. Skorohod A V 1967 Random processes with independent increments Nauka Moscow Russian Federation.

320. Gikhman I I, Skorohod A V 1968 Stochastic differential equations Naukova Dumka Kiev Ukraine.

321. Gikhman I I, Skorohod A V 1969 Introduction to the theory of random processes $1^{\text {st }}$ edition Saunders Philadelphia USA.

322. Gikhman I I, Skorohod A V 1974-1979 Theory of stochastic processes vols 1, 2, 3 Springer-Verlag New York-Berlin USA-Germany.

323. Breiman L 1968 Probability Addison-Wesley Reading MA USA.

324. Feller W 1968 An introduction to probability theory and its applications vols $\mathbf{1}, 23^{\text {rd }}$ edition John Wiley and Sons Inc New York USA.

325. Brush S G 1968, 1977 A history of random processes: 1. Brownian movement in Study history statistics and probability Kendall M G, Plackett R L (editors) 2 pp 347 - 382 London UK.

326. Glesjer H 1969 A new test for heteroskedasticity Journal of the American Statistical Association 64 pp 316 - 323.

327. Ash R B 1970 Basic probability theory John Wiley and Sons Inc New York USA.

328. Ash R B 1972 Real analysis and probability Academic Press New York USA.

329. Ash R B, Gardner M F 1975 Topics in stochastic processes Academic Press New York USA.

330. Box G E P, Jenkins G M 1970 Time series analysis: Forecasting and control Holden Day San Francisco California USA.

331. Renyi A 1970 Probability theory North-Holland Publishing Company Amsterdam The Netherlands.

332. Isihara A 1971 Statistical physics Academic Press New York USA. 
333. Brent R P 1973 Algorithms for minimization without derivatives Englewood Cliffs USA.

334. Rubin D B 1974 Estimating causal effects of treatments in randomized and nonrandomized studies Journal of Educational Psychology 55 (5) pp 688 - 701.

335. Borovkov A A 1976 Wahrscheinlichkeitstheorie: Eine EinjUhrung $1^{\text {st }}$ edition Birkhiuser Basel-Stuttgart Switzerland-Germany.

336. Grangel C W J, Newbold P 1977 Forecasting economic time series Academic Press New York USA.

337. Grangel C W J, Teräsvirta T 1993 Modeling nonlinear economic relationships Oxford University Press Oxford New York UK USA.

338. Pugachev V S 1979 Theory of probability and mathematical statistics $1^{\text {st }}$ edition Nauka Moscow Russian Federation, $2^{\text {nd }}$ edition Fizmatlit Moscow Russian Federation ISBN 5-92210254-0 pp 1 - 496.

339. Ross S M 1980 Introduction to probability models Academic Press New York USA.

340. Karlin S, Taylor H M 1981 A second course in stochastic processes Academic Press New York USA.

341. Venttsel A D 1981 A course in the theory of stochastic processes McGraw-Hill New York USA.

342. Maddala G S 1983 Limited-dependent and qualitative variables in econometrics Cambridge University Press Cambridge UK.

343. Yaglom A M, Yaglom I M 1983 Probability and information Reidel Dordrecht.

344. Heckman J, Singer B 1984a A method for minimizing the impact of distributional assumptions in econometric models for duration data Econometrica 52 pp 271 - 320.

345. Heckman J, Singer B 1984b Econometric duration analysis Journal of Econometrics 24 pp $63-132$.

346. Pagan A 1984 Econometric issues in the analysis of regressions with generated regressors International Economic Review 25 pp 221 - 247.

347. Van Horne J C 1984 Financial market rates and flows Prentice Hall Englewood Cliffs NJ USA.

348. Murphy K M, Topel R H October 1985 Estimation and inference in two-step econometric models Journal of Business and Economic Statistics 3 pp 370 - 379.

349. Neter J, Wasserman W, Kutner M H 1985 Applied linear statistical models $2^{\text {nd }}$ edition Irwin Homewood USA.

350. Powell J L 1986 Censored regression quantiles Journal of Econometrics 32 (1) pp $143-155$. 
351. Taylor S 1986 Modeling financial time series John Willey and Sons Inc New York USA.

352. Tong H 1986 Nonlinear time series Oxford University Press Oxford UK.

353. Tornqvist L, Vartia P, Vartia Y February 1985 How should relative change be measured? American Statistician 39 pp 43 - 46.

354. Sharkovsky A N, Maistrenko Yu L, Romanenko E Yu 1986 Differential equations and their applications Naukova Dumka Kiev Ukraine pp 1 - 280.

355. Newey W, West K 1987 A simple positive semi-definite, heteroskedasticity and autocorrelation consistent covariance matrix Econometrica 55 pp 703 - 708.

356. Luukkonen R, Saikkonen P, Terasvirta T 1988 Testing linearity against smooth transition autoregressive models Biometrika 75 pp 491 - 499.

357. Judge G, Hill C, Griffiths W, Lee T, Lutkepol H 1988 An introduction to the theory and practice of econometrics $2^{\text {nd }}$ edition John Wiley and Sons Inc New York USA.

358. Hardle W 1990 Applied nonparametric regression Econometric Society Monograph Cambridge University Press Cambridge UK.

359. Lancaster T 1990 The econometric analysis of transition data Cambridge University Press Cambridge UK.

360. Tong H 1990 Nonlinear time series: A dynamical system approach Clarendon Press Oxford UK.

361. Johansen S 1992 Cointegration in partial systems and the efficiency of single equation analysis Journal of Econometrics $\mathbf{5 2}$ pp 389 - 402.

362. Banerjee A, Dolado J J, Galbraith J W, Hendry D F 1993 Cointegration, error correction, and the econometric analysis of nonstationary data Oxford University Press Oxford UK.

363. Cleveland W S 1993 Visualizing data Hobart Press Summit New Jersey USA.

364. Pesaran M H, Potter S M (editors) 1993 Nonlinear dynamics, chaos and econometrics John Willey and Sons Inc New York USA.

365. Hamilton J D 1994 Time series analysis Princeton University Press Princeton, NJ USA.

366. Peters E E 1994 Fractal market analysis: Applying chaos theory to investment and economics John Wiley and Sons Inc New York USA.

367. Enders W 1995 Applied econometric time series John Wiley and Sons Inc New York USA.

368. Johansen S 1995 Likelihood based inference in co-integrated vector autoregressive models Oxford University Press Oxford UK.

369. Karatzas I, Shreve S 1995 Methods of mathematical finance Columbia University Press New York USA. 
370. Moore G E 1995 Lithography and the future of Moore's law Proceedings SPIE Symposium Optical Microlithography Conference VIII 24402.

371. Moore G E 2003 No exponential is forever - but we can delay forever ISSCC.

372. Campbell J Y, Lo A W, MacKinlay A C 1996 The econometrics of financial markets Princeton University Press Princeton USA.

373. Mosekilde E 1996 Topics in nonlinear dynamics: Applications to physics, biology and economic systems World Scientific Publishing Pte Ltd Singapore.

374. Rogers L C G, Talay D (editors) 1997 Numerical methods in finance Cambridge University Press Cambridge UK.

375. Campbell J, Lo A, MacKinlay C 1997 The econometrics of financial markets Princeton University Press Princeton NJ USA.

376. Greene W H 1997, 1999, 2003 Econometric analysis $1^{\text {st }}$ edition, $4^{\text {th }}$ edition, $5^{\text {th }}$ edition Prentice Hall Upper Saddle River USA.

377. Hasem P M, Pesaran B 1997 Working with Microfit 4.0: Interactive econometric analysis Oxford University Press Oxford UK.

378. Lo A W, MacKinlay A C 1997 The econometrics of financial markets Princeton University Press Princeton New Jersey USA.

379. Anderson H M, Vahid F 1998 Testing multiple equation systems for common nonlinear factors Journal of Econometrics 84 pp 1 - 37.

380. Hubbard B B 1998 The world according to wavelets A K Peters Wellesley MA USA.

381. Mallat S A 1998 Wavelet tour of signal processing Academic Press San Diego CA USA.

382. Teolis A 1998 Computational signal processing with wavelets Birkhauser Switzerland.

383. Anishenko V S, Vadivasova T E, Astakhov V V 1999 Nonlinear Dynamics of Chaotic and Stochastic Systems Saratov University Publishing House Saratov Russian Federation.

384. Escribano, Jorda 1999 Improved testing and specification of smooth transition regression models in Nonlinear time series analysis of economic and financial data Rothman (editor) Kluwer Academic Press Amsterdam The Netherlands.

385. Hasem P M, Shin Y 1999 An autoregressive distributed lag modelling approach to cointegration analysis in Econometrics and economic theory in the 20th century: The Ranger Frisch centennial symposium Strom S, Holly A, Diamond P (editors) Cambridge University Press Cambridge UK www.econ.cam.ac.uk/faculty/pesaran/ADL.pdf .

386. Hasem P M, Shin Y, Smith R J 2001 Bounds testing approaches to the analysis of level relationships Journal of Applied Econometrics 16 (3) pp 289 - 326. 
387. Potter S 1999 Non-linear time series modelling: An introduction Typescript Federal Reserve Bank of New York NY USA.

388. Rothman (editor) 1999 Nonlinear time series analysis of economic and financial data Kluwer Academic Press Amsterdam The Netherlands.

389. Hayashi F 2000 Econometrics Princeton University Press Princeton NJ USA.

390. Durbin J, Koopman S J 2000 Time series analysis of non-Gaussian observations based on state-space models from both classical and Bayesian perspectives Journal of Royal Statistical Society Series B 62 pp 3 - 56.

391. Durbin J, Koopman S J 2002 A simple and efficient simulation smoother for state space time series analysis Biometrika 89 pp $603-615$.

392. Durbin J, Koopman S J 2012 Time series analysis by state space methods $2^{\text {nd }}$ edition Oxford University Press Oxford UK.

393. Ilinski K 2001 Physics of finance: Gauge modelling in non-equilibrium pricing John Wiley and Sons Inc New York USA ISBN-10: 0471877387 pp 1 - 300.

394. Kuznetsov S P 2001 Dynamic chaos Izdatel'stvo Fiziko-Matematicheskoi Literatury Moscow Russian Federation pp 1 - 296.

395. Tufte E R 2001 The visual display of quantitative information $2^{\text {nd }}$ edition Graphics Press Cheshire CT USA.

396. Nicolau J 2002 Stationary processes that look like random walks - The bounded random walk process in discrete and continuous time Econometric Theory 18 pp 99 - 118.

397. Ledenyov V O, Ledenyov O P, Ledenyov D O 2002 A quantum random number generator on magnetic flux qubits Proceedings of the $2^{\text {nd }}$ Institute of Electrical and Electronics Engineers Conference IEEE-NANO 2002 Chicago Washington DC USA IEEE Catalog no 02TH86302002 Library of Congress number: 2002106799 ISBN: 0-7803-7538-6.

398. Woolridge J M 2002 Econometric analysis of cross section and panel data MIT Press Cambridge MA USA.

399. Koop G 2003 Bayesian econometrics John Wiley and Sons Inc New York USA.

400. Selover D D, Jensen R V, J. Kroll J 2003 Studies in Nonlinear Dynamics \& Econometrics 71.

401. Davidson R, MacKinnon J 2004 Econometric theory and methods Oxford University Press Oxford UK.

402. Cameron A C, Trivedi P K 2005 Microeconometrics: Methods and applications Cambridge University Press Cambridge UK.

403. Protter P E 2005 Stochastic integration and differential equations Springer Germany. 
404. Backhaus $\mathrm{K}$ et al 2006 Multivariate analysemethoden. Eine anwendungsorientierte einführung Springer Berlin Heidelberg Germany.

405. Damodaran A 2006 Applied corporate finance. A user' manual $2^{\text {nd }}$ edition John Wiley \& Sons Inc New Jersey USA.

406. Ernst D, Häcker J 2007 Applied international corporate finance Vahlen München Germany.

407. Angrist J D, Pischke J-S 2008 Mostly harmless econometrics: An empiricist's companion Princeton University Press USA.

408. Vialar Th, Goergen A 2009 Complex and chaotic nonlinear dynamics Springer-Verlag Berlin Heidelberg Germany ISBN 978-3-540-85977-2 pp 1 - 752.

409. Weatherall J O 2013 Physics of Wall Street Houfton New York USA.

\section{Selected Research Papers in Economics Science:}

410. Ledenyov V O, Ledenyov D O 2012a Shaping the international financial system in century of globalization Cornell University NY USA www.arxiv.org 1206.2022.pdf pp $1-20$.

411. Ledenyov V O, Ledenyov D O 2012b Designing the new architecture of international financial system in era of great changes by globalization Cornell University NY USA Www.arxiv.org 1206.2778.pdf pp $1-18$.

412. Ledenyov D O, Ledenyov V O 2012a On the new central bank strategy toward monetary and financial instabilities management in finances: econophysical analysis of nonlinear dynamical financial systems Cornell University NY USA www.arxiv.org 1211.1897.pdf pp $1-8$.

413. Ledenyov D O, Ledenyov V O 2012b On the risk management with application of econophysics analysis in central banks and financial institutions Cornell University NY USA www.arxiv.org 1211.4108.pdf pp $1-10$.

414. Ledenyov D O, Ledenyov V O 2013a On the optimal allocation of assets in investment portfolio with application of modern portfolio management and nonlinear dynamic chaos theories in investment, commercial and central banks Cornell University NY USA www.arxiv.org 1301.4881.pdf pp $1-34$.

415. Ledenyov D O, Ledenyov V O 2013b On the theory of firm in nonlinear dynamic financial and economic systems Cornell University NY USA www.arxiv.org 1206.4426v2.pdf pp $1-27$. 
416. Ledenyov D O, Ledenyov V O 2013c On the accurate characterization of business cycles in nonlinear dynamic financial and economic systems Cornell University NY USA www.arxiv.org 1304.4807.pdf pp $1-26$.

417. Ledenyov D O, Ledenyov V O 2013d To the problem of turbulence in quantitative easing transmission channels and transactions network channels at quantitative easing policy implementation by central banks Cornell University NY USA www.arxiv.org 1305.5656.pdf pp $1-40$.

418. Ledenyov D O, Ledenyov V O 2013e To the problem of evaluation of market risk of global equity index portfolio in global capital markets MPRA Paper no 47708 Munich University Munich Germany pp $1-25$ http://mpra.ub.uni-muenchen.de/47708/ .

419. Ledenyov D O, Ledenyov V O $2013 \mathrm{f}$ Some thoughts on accurate characterization of stock market indexes trends in conditions of nonlinear capital flows during electronic trading at stock exchanges in global capital markets MPRA Paper no 49964 Munich University Munich Germany pp $1-52$ http://mpra.ub.uni-muenchen.de/49964/ .

420. Ledenyov D O, Ledenyov V O 2013g On the Stratonovich - Kalman - Bucy filtering algorithm application for accurate characterization of financial time series with use of statespace model by central banks MPRA Paper no 50235 Munich University Munich Germany pp $1-52$ http://mpra.ub.uni-muenchen.de/50235/ .

421. Ledenyov D O, Ledenyov V O 2013h Tracking and replication of hedge fund optimal investment portfolio strategies in global capital markets in presence of nonlinearities MPRA Paper no 51176 Munich University Munich Germany pp 1 - 92 http://mpra.ub.uni-muenchen.de/51176/ .

422. Ledenyov D O, Ledenyov V O 2013i Venture capital optimal investment portfolio strategies selection in diffusion - type financial systems in global capital markets with nonlinearities MPRA Paper no 51903 Munich University Munich Germany pp 1 - 81 http://mpra.ub.uni-muenchen.de/51903/ .

423. Ledenyov D O, Ledenyov V O 2014a Mergers and acquisitions transactions strategies in diffusion - type financial systems in highly volatile global capital markets with nonlinearities MPRA Paper no 61946 Munich University Munich Germany, SSRN Paper no SSRN-id2561300 Social Sciences Research Network New York USA pp 1 - 160 http://mpra.ub.uni-muenchen.de/61946/, 
www.ssrn.com SSRN-id2561300.pdf .

424. Ledenyov D O, Ledenyov V O 2014b Strategies on initial public offering of company equity at stock exchanges in imperfect highly volatile global capital markets with induced nonlinearities MPRA Paper no 53780 Munich University Munich Germany, SSRN Paper no SSRN-id2577767 Social Sciences Research Network New York USA pp 1 - 138 http://mpra.ub.uni-muenchen.de/53780/, www.ssrn.com SSRN-id2577767.pdf .

425. Ledenyov D O, Ledenyov V O 2014c On the winning virtuous strategies for ultra high frequency electronic trading in foreign currencies exchange markets MPRA Paper no 61863 Munich University Munich Germany, SSRN Paper no SSRN-id2560297 Social Sciences Research Network New York USA pp 1-175

http://mpra.ub.uni-muenchen.de/61863/, www.ssrn.com SSRN-id2560297.pdf .

426. Ledenyov D O, Ledenyov V O 2014d On the fundamentals of winning virtuous strategies creation toward leveraged buyout transactions implementation during private equity investment in conditions of resonant absorption of discrete information in diffusion - type financial system with induced nonlinearities MPRA Paper no 61805 Munich University Munich Germany pp 1 - 161, SSRN Paper no SSRN-id2559168 Social Sciences Research Network New York USA

http://mpra.ub.uni-muenchen.de/61805/, www.ssrn.com SSRN-id2559168.pdf .

427. Ledenyov D O, Ledenyov V O 2014e MicroFX foreign currencies ultra high frequencies trading software platform with embedded optimized Stratonovich - Kalman - Bucy filtering algorithm, particle filtering algorithm, macroeconomic analysis algorithm, market microstructure analysis algorithm, order flow analysis algorithm, comparative analysis algorithm, and artificial intelligence algorithm for near-real-time decision making / instant switching on / between optimal trading strategies ECE James Cook University Townsville Australia, Kharkov Ukraine.

428. Ledenyov D O, Ledenyov V O 2014f MicroLBO software program with the embedded optimized near-real-time artificial intelligence algorithm to create winning virtuous strategies toward leveraged buyout transactions implementation and to compute direct/reverse leverage buyout transaction default probability number for selected public/private companies during private equity investment in conditions of resonant absorption of discrete information in 
diffusion - type financial system with induced nonlinearities ECE James Cook University Townsville Australia, Kharkov Ukraine.

429. Ledenyov D O, Ledenyov V O 2015b Winning virtuous strategy creation by interlocking interconnecting directors in boards of directors in firms in information century MPRA Paper no 61681 Munich University Munich Germany, SSRN Paper no SSRN-id2553938 Social Sciences Research Network New York USA pp 1 - 108

http://mpra.ub.uni-muenchen.de/61681/, www.ssrn.com SSRN-id2553938.pdf .

430. Ledenyov D O, Ledenyov V O 2015c Information theory of firm MPRA Paper no 63380 Munich University Munich Germany, SSRN Paper no SSRN-id2587716 Social Sciences Research Network New York USA pp 1 - 185

http://mpra.ub.uni-muenchen.de/63380/, www.ssrn.com SSRN-id2587716.pdf .

431. Ledenyov D O, Ledenyov V O 2015d MicroID software program with the embedded optimized near-real-time artificial intelligence algorithm to create the winning virtuous business strategies and to predict the director's election / appointment in the boards of directors in the firms, taking to the consideration both the director's technical characteristics and the interconnecting interlocking director's network parameters in conditions of the resonant absorption of discrete information in diffusion - type financial economic system with induced nonlinearities ECE James Cook University Townsville Australia, Kharkov Ukraine.

432. Ledenyov D O, Ledenyov V O 2015e MicroITF operation system and software programs: 1) the operation system to control the firm operation by means of the information resources near-real-time processing in the modern firms in the case of the diffusion - type financial economic system with the induced nonlinearities; 2) the software program to accurately characterize the director's performance by means of a) the filtering of the generated/transmitted/received information by the director into the separate virtual channels, depending on the information content, and b) the measurement of the levels of signals in every virtual channel with the generated/transmitted/received information by the director, in the overlapping interconnecting interlocking directors networks in the boards of directors in the firms during the Quality of Service (QofS) measurements process; and 3) the software program to create the winning virtuous business strategies by the interlocking interconnecting directors in the boards of directors in the modern firms in the case of the diffusion - type financial economic system with the induced nonlinearities, using the patented 
recursive artificial intelligence algorithm ECE James Cook University Townsville Australia, Kharkov Ukraine.

433. Ledenyov D O, Ledenyov V O 2015f MicroIMF software program: the MicroIMF software program to make the computer modeling of 1) the interactions between the information money fields of one cyclic oscillation and the information money fields of other cyclic oscillation(s) in the nonlinear dynamic economic system, 2) the interactions between the information money fields of cyclic oscillation and the nonlinear dynamic economic system itself, and 3) the density distributions of the information money fields by different cyclic oscillations (the economic continuous waves) in the nonlinear dynamic economic system ECE James Cook University Townsville Australia, Kharkov Ukraine.

Electromagnetic Field, Gravitation Field, Calibrating Field, Information Field Theories in

\section{Physics and Engineering Sciences:}

434. Maxwell J C 1890 Introductory lecture on experimental physics in Scientific papers of J C Maxwell Niven W D (editor) vols 1, 2 Cambridge UK.

435. Ledenyov D O, Ledenyov V O 2015a Nonlinearities in microwave superconductivity $7^{\text {th }}$ edition Cornell University NY USA www.arxiv.org 1206.4426v7.pdf pp $1-923$. 